(C) 2020, The Authors. Published by FASS Inc. and Elsevier Inc. on behalf of the American Dairy Science Association ${ }^{\circledR}$. This is an open access article under the CC BY-NC-ND license (http://creativecommons.org/licenses/by-nc-nd/4.0/).

\title{
Effects of 2 colostrum and subsequent milk replacer feeding intensities on methane production, rumen development, and performance in young calves
}

\author{
Lisa-Maria Tümmler, ${ }^{1} \odot$ Michael Derno, ${ }^{1} \odot$ Volker Röttgen, ${ }^{2,3}$ Andreas Vernunft, ${ }^{2}$ Armin Tuchscherer, ${ }^{4}$ \\ Petra Wolf, ${ }^{5}$ (D) and Björn Kuhla ${ }^{1 *}$ (D) \\ ${ }^{1}$ Institute of Nutritional Physiology "Oskar Kellner," Leibniz Institute for Farm Animal Biology (FBN), 18196 Dummerstorf, Germany \\ ${ }^{2}$ Institute of Reproductive Physiology, Leibniz Institute for Farm Animal Biology (FBN), 18196 Dummerstorf, Germany \\ ${ }^{3}$ Institute of Behavioural Physiology, Leibniz Institute for Farm Animal Biology (FBN), 18196 Dummerstorf, Germany \\ ${ }^{4}$ Institute of Genetics and Biometry, Leibniz Institute for Farm Animal Biology (FBN), 18196 Dummerstorf, Germany \\ ${ }^{5}$ Faculty of Agricultural and Environmental Sciences, University Rostock, 18059 Rostock, Germany
}

\section{ABSTRACT}

A growing need exists for the development of practical feeding strategies to mitigate methane $\left(\mathrm{CH}_{4}\right)$ emissions from cattle. Therefore, the objective of this study was to evaluate the influence of milk replacer feeding intensity (MFI) in calves on $\mathrm{CH}_{4}$ emission, rumen development, and performance. Twenty-eight female newborn Holstein calves were randomly assigned to 2 feeding groups, offered daily either $10 \%$ of the body weight (BW) in colostrum and subsequently $10 \%$ of the $\mathrm{BW}$ in milk replacer (MR; 10\%-MR), or $12 \%$ of the BW in colostrum followed by $20 \%$ of the $\mathrm{BW}$ in MR (20\%-MR). In wk 3, half of each feeding group was equipped with a permanent rumen cannula. Both groups were weaned at the end of wk 12. Hay and calf starter (mixture of pelleted grains) were offered from d 1 until wk 14 and 16, respectively. A total mixed ration was offered from wk 11 onward. Feed intake was measured daily and BW, anatomical measures, and rumen size weekly. Methane production and gastrointestinal passage rate were measured pre-weaning in wk 6 and 9 and post-weaning in wk 14 and 22, with additional estimation of organic matter digestibility. Rumen fluid, collected in wk 1, 2, 3, 6, 9, 14, 18, and 22 , was analyzed for volatile fatty acid concentrations. Although the experimental period ended in wk 23 , rumen volume of 17 calves was determined after slaughter in wk 34. Data was analyzed using ANOVA for the effects of feeding group, cannulation, and time, if applicable. Dry matter intake (DMI) of solid feed (SF) in 20\%-MR animals was lower pre-weaning in wk 6 to 10 but mostly higher post-weaning. From wk 6

Received November 8, 2019

Accepted March 11, 2020.

*Corresponding author: b.kuhla@fbn-dummerstorf.de onward, anatomical measures and BW were greater in $20 \%$-MR animals, and only the differences in body condition score gradually ceased post-weaning. Following the amount of SF intake, $10 \%$-MR calves emitted more $\mathrm{CH}_{4}$ pre-weaning in wk 9, whereas post-weaning the 20\%-MR group tended to have higher levels. Methane emission intensity $\left(\mathrm{CH}_{4} / \mathrm{BW}\right)$ was lower pre-weaning in $20 \%$-MR animals but was comparable to the $10 \%$-MR group post-weaning. Methane yield $\left(\mathrm{CH}_{4} / \mathrm{DMI}\right.$ of $\left.\mathrm{SF}\right)$ and estimated post-weaning organic matter digestibility were not affected by MFI. Rumen size normalized to heart girth was greater in $10 \%$-MR calves from wk 5 to 10 , but differences did not persist thereafter. In wk 34 , rumen volume was higher in $20 \%$-MR calves, but normalization to BW revealed no difference between feeding groups. In conclusion, high MFI reduces $\mathrm{CH}_{4}$ emission from calves pre-weaning, although this effect ceases post-weaning.

Key words: calf, methane, rumen cannulation, rumen size, digestibility

\section{INTRODUCTION}

Enteric methane $\left(\mathrm{CH}_{4}\right)$ emissions account for approximately $40 \%$ of total greenhouse gas emission from the livestock supply chain (Gerber et al., 2013). Thereof, $77 \%$ are contributed by cattle (Gerber et al., 2013). Total greenhouse gas emission from the livestock supply chain represents approximately $15 \%$ of all human-induced emissions (Gerber et al., 2013). Methane is a byproduct of ruminal fermentation, and in the atmosphere its warming potential in a 100-yr time frame is 28 to 34 times greater than that of $\mathrm{CO}_{2}$ (Myhre et al., 2013). Due to a growing need for action, the Intergovernmental Panel on Climate Change has pointed out the important role of $\mathrm{CH}_{4}$ emission reductions to minimize global warming by $1.5^{\circ} \mathrm{C}$ (Rogelj et al., 2018). The report explicitly demands improvement 
of feeding strategies to reduce $\mathrm{CH}_{4}$ emissions from ruminants (Rogelj et al., 2018). Emission mitigation strategies for cattle by dietary means have focused mainly on adult animals, but their effect is often only short-lasting. For example, the inhibitory effect of the ionophore monensin on $\mathrm{CH}_{4}$ may not persist, because microorganisms adapt to the treatment after 2 to $5 \mathrm{wk}$ (Guan et al., 2006).

In the past 2 decades, research has started to focus on the intervention of rumen colonization in young and growing ruminants, as the developing rumen potentially offers a better chance to manipulate archaeal colonization in the rumen to achieve long-term effects on reduction of $\mathrm{CH}_{4}$ emission (Yáñez-Ruiz et al., 2015). Supplementing the diet with rhubarb, an herbaceous perennial, from the age of 40 to $50 \mathrm{~d}$ significantly reduced the abundance of the archaea Methanimicrococcus spp. and increased the abundance of Methanobrevibacter (Wang et al., 2017). The addition of bromochloromethane to grain fed to goat kids over 3 mo after birth diminished $\mathrm{CH}_{4}$ emissions by approximately $50 \%$. When, in parallel, does were treated with bromochloromethane until weaning, the effect persisted until 3 mo after the treatment of kids ceased (Abecia et al., 2013). Feeding growing lambs with $50 \%$ milk replacer (MR) and 50\% cream from d 3 to 180 of age has been reported to reduce $\mathrm{CH}_{4}$ emission and $\mathrm{CH}_{4}$ yield by 84 to $87 \%$ and almost deleted methanogenic sequence counts in rumen fluid, relative to lambs on a hay-based diet (Haque et al., 2014).

Feeding calves with MR instead of cream is more practically relevant, but to our knowledge, its effect on $\mathrm{CH}_{4}$ emission has not yet been studied. An elevated milk or MR feeding intensity (MFI) is known to depress starter (Silva et al., 2019) and hay intake (Broesder et al., 1990), thereby potentially delaying rumen development relative to calves fed MR restrictively (Khan et al., 2011). As discussed by Dennis et al. (2019), delay of rumen development is associated with lower OM digestibility, which, in turn, may decrease $\mathrm{CH}_{4}$ yield (Huhtanen et al., 2016). Considering that 2 main driving factors determining $\mathrm{CH}_{4}$ production are the amount of DMI (Ramin and Huhtanen, 2013) and OM digestibility (Jentsch et al., 2007), we hypothesized that an elevated MFI reduces total $\mathrm{CH}_{4}$ production, $\mathrm{CH}_{4}$ emission intensity expressed as $\mathrm{CH}_{4} / \mathrm{BW}$ per day, and methane yield, expressed as $\mathrm{CH}_{4} / \mathrm{DMI}$ of solid feed (SF). Thus, the aim of the present study was to investigate the short- and long-term effects of divergent MFI on $\mathrm{CH}_{4}$ production, development of rumen size and ruminal fermentation, estimated OM digestibility, passage rate, and performance in dairy calves pre- and post-weaning.

\section{MATERIALS AND METHODS}

\section{Animals, Experimental Design, and Diets}

All procedures were in accordance with the German Animal Welfare Act and approved by the local ethics committee of the State Government in MecklenburgWest Pomerania, Rostock, Germany (Landesamt für Landwirtschaft, Lebensmittelsicherheit und Fischerei, Mecklenburg-Vorpommern; approval No. 7221.3-1.1009/16).

The experiment was conducted at the Leibniz Institute for Farm Animal Biology (FBN), Dummerstorf, Germany. A total of 28 female newborn Holstein calves, acquired from the FBN and from 2 dairy farms located nearby, were used in this study. Calves were separated from their dams immediately after birth and moved to the calf barn at FBN without colostrum feeding. Animals were weighed and housed in individual pens bedded with wood shavings, with free access to water. The animals were randomly allocated to 2 feeding groups, fed MR at either $10 \%(\mathbf{1 0 \%}-\mathbf{M R} ; \mathrm{n}=14)$ or $20 \%$ (20\%-MR; $\mathrm{n}=14)$ of their BW per d after a 2.5-d period of colostrum feeding. The colostrum feeding rate was $10 \%$ of the BW for the $10 \%$-MR group and from 12 to $14 \%$ of the BW for the $20 \%$-MR group. The different colostrum and subsequent MR feeding intensities were applied to induce different SF intake levels. Because rumen colonization and fermentation begin in the first day of life, colostrum intensities were adjusted according to MR feeding intensities. At wk $3(18.4 \mathrm{~d} \pm 0.8)$, half of each feeding group $(\mathrm{n}=7)$ was equipped with a permanent rumen cannula $[3.5-\mathrm{cm}$ outer diameter (o.d.)] on the left dorsolateral flank. The experimental period lasted until the end of wk 23. Thereafter, 17 animals were slaughtered in wk 34 to measure reticulorumen volume (RRV). Supplemental Figure S1 (https: //doi.org/10.3168/jds.2019-17875) gives an overview of experimental design and feeding regimen.

\section{Colostrum}

Calves were fed colostrum in 5 meals from suckling buckets during the first $2.5 \mathrm{~d}$ of life. On d 1 and 2, the 10\%-MR group was offered daily $10 \%$ of the birth weight in colostrum (2 feedings daily, $5 \%$ per meal) and the $20 \%$-MR group $12 \%$ of the birth weight ( 2 feedings daily, $6 \%$ per meal), respectively. On d 3 , the $10 \%$-MR group was offered $5 \%$ of the birth weight in colostrum (first meal) and subsequently $5 \%$ of the birth weight in MR (second meal) and the $20 \%$-MR group $7 \%$ of the birth weight in colostrum (first meal) and $7 \%$ of the birth weight in MR (second meal), respectively. In 
total, the $10 \%$-MR calves drank $10.3 \pm 0.3 \mathrm{~L}$ and the $20 \%$-MR calves $12.4 \pm 0.6 \mathrm{~L}$ of colostrum. All calves received the same colostrum from 3 pools (meal $1+2$, meal $3+4$, and meal 5) kept aliquoted at $-20^{\circ} \mathrm{C}$. The first colostrum meal was fed immediately after arrival at the FBN within a period of 2 to $8 \mathrm{~h}$ after birth. The time between meals 1 and 2 was at least $4 \mathrm{~h}$. Calves with the first colostrum meal before $2000 \mathrm{~h}$ received the second meal between 1700 and 2359 h the same day, whereas calves with the first colostrum meal after 2000 $\mathrm{h}$ received only 1 meal on $\mathrm{d} 1$. Subsequent colostrum meals were fed between 0630 to 0730 and 1730 to 1830 h. Calves that did not ingest the whole amount of a meal within 30 min were offered the remaining amount between the morning and afternoon feeding times.

\section{Milk Replacer}

After the period of colostrum feeding, calves were supplied with MR (BERGIN Milch LC 50, Bergophor Futtermittelfabrik Dr. Berger GmbH \& Co. KG, Kulmbach, Germany; $140 \mathrm{~g}$ of powder/kg; Supplemental Table S1, https://doi.org/10.3168/jds.2019-17875) by an automatic calf feeder system (Kälbermama Lifestart, Urban GmbH \& Co. KG, Hude/Wüsting, Germany). The calves were weighed weekly to adjust the daily amount of MR according to the feeding group. The daily amount of MR was provided in 4 equal portions per day. After wk 6, the 20\%-MR group received 6 equal portions per day. Milk replacer feeding of the $20 \%$-MR group was gradually reduced to $10 \%$ of the BW from wk 9 to the end of wk 10. Gradual weaning for both groups took place from wk 11 to the end of wk 12 .

\section{Solid Feed}

Long-stemmed grass hay was offered for ad libitum intake until the end of wk 14 and starter $(0.3 \times 14-\mathrm{mm}$ pellets) for ad libitum intake until the end of wk 12 . Thereafter, the allowance of starter was limited to 2 $\mathrm{kg} / \mathrm{d}$ in wk 13 and 14 and was gradually reduced to 0 $\mathrm{kg}$ in wk 15 and 16. A TMR (Supplemental Table S2, https://doi.org/10.3168/jds.2019-17875) was offered for ad libitum intake from wk 11 onward. Feed intake was measured daily by manually weighing the offered feed and the remaining feed on the following day.

\section{Feed Sampling and Analyses}

Hay, starter, and MR samples were taken from every batch. The TMR samples were taken in wk 14 and 22 in parallel to every respiration chamber measurement for chemical analysis and weekly for DM analysis. Feed samples were dried at $60^{\circ} \mathrm{C}$ for $24 \mathrm{~h}$ and subsequently at $103^{\circ} \mathrm{C}$ for $4 \mathrm{~h}$ to determine $\mathrm{DM}$ content. Nutrient compositions were analyzed by the accredited service laboratory of Landwirtschaftliche Untersuchungs- und Forschungsanstalt der LMS Agrarberatung GmbH (LUFA, Rostock, Germany) and are shown in Supplemental Table S1 (https://doi.org/10.3168/jds.2019 $-17875)$.

\section{BW and Anatomical Measures}

Body weight, heart girth (HG), wither height, body length, and BCS were determined weekly as described by Raschke (2007). Body length was defined as the scapulo-ischial length and was measured on the left side of the animals. Body condition score was determined according to the system described by Edmonson et al. (1989), modified by Metzner et al. (1993), and further adapted for calves by Raschke (2007).

\section{Measurements in Respiration Chambers and Calculations}

Methane production (L/d) was determined 2 times before and 2 times after weaning in open-circuit respiration chambers as described by Derno et al. (2009). Animals were transferred into the chamber 12 to $16 \mathrm{~h}$ before initiation of the measurement, to achieve gas exchange equilibration. Mean recovery rates of the 4 chambers were $100.9 \pm 0.7 \%, 99.8 \pm 0.3 \%, 99.5 \pm$ $0.4 \%$, and $100.7 \pm 0.4 \%$. Concentrations of $\mathrm{CH}_{4}$ in the chamber air were measured by infrared absorption (SIDOR, SICK MAIHAK GmbH, Reute, Germany). The airflow through the chamber (approximately 10 $\mathrm{m}^{3} / \mathrm{h}$ ) was measured by a differential pressure-type $\mathrm{V}$ cone flow meter (McCrometer, Hemet, CA).

Measurements were conducted for 2 consecutive 24-h periods in wk $6(36.6 \pm 0.5 \mathrm{~d}), 9(58.4 \pm 0.5 \mathrm{~d}), 14$ $(92.9 \pm 0.7 \mathrm{~d})$, and $22(149.8 \pm 0.6 \mathrm{~d})$. The animals had free access to water and were kept at $18^{\circ} \mathrm{C}$ in wk 6 and at $15^{\circ} \mathrm{C}$ for the remaining measurements. In wk 6 MR was fed with a suckling bucket in 3 equal portions at 0700,1300 , and $1800 \mathrm{~h}$ with daily amounts according to the feeding group. In wk 9 , the $10 \%$-MR group was fed again 3 equal portions at 0700, 1300, and 1800 $\mathrm{h}$, whereas the $20 \%$-MR group received 4 equal portions at $0700,1000,1300$, and $1800 \mathrm{~h}$. Hay, starter, and TMR were offered at $0730 \mathrm{~h}$ in troughs according to the feeding regimen described above, except that in wk 22 TMR was offered in a trough with a scale connected to an electronic registration device to measure the intake (PAARI, Erfurt, Germany). Body weight was measured immediately before and after every respiration chamber measurement, and the mean of both values was used 
for calculation of $\mathrm{CH}_{4}$ emission intensity ( $\mathrm{L} / \mathrm{d}$ per $\mathrm{kg}$ of $\mathrm{BW}$ ). Methane yield was defined as $\mathrm{CH}_{4}$ production per DMI of solid feed $(\mathrm{L} / \mathrm{kg})$. Data for $\mathrm{CH}_{4}$ yield of 4 animals from the 20\%-MR group in wk 6 was excluded due to zero DMI. Methane production, $\mathrm{CH}_{4}$ yield, and $\mathrm{CH}_{4}$ intensity are given as means from both consecutive 24-h measurements. Due to animal health or technical issues in 3 cases on d 2 of the chamber trial, only the data of the first 24-h measuring period could be used ( 2 in wk 14 and 1 in wk 22). In 1 further case in wk 6 , whole measurements in the chamber could not be performed.

For the estimation of cumulative $\mathrm{CH}_{4}$ production over the whole experimental period, means of daily $\mathrm{CH}_{4}$ production of every feeding group were extrapolated as follows. Methane production $(\mathrm{L} / \mathrm{d})$ was assumed to be 0 on $\mathrm{d} 0$ and to increase linearly between the data points. Extrapolation ended at wk 22 with the last $\mathrm{CH}_{4}$ measurement. Based on the regression line, $\mathrm{CH}_{4}$ production was calculated for each day as the mean for each group, and cumulative $\mathrm{CH}_{4}$ production was calculated as sum for the pre- and post-weaning period. Because extrapolation results in more estimated than measured daily $\mathrm{CH}_{4}$ production, the uncertainty in estimating cumulative $\mathrm{CH}_{4}$ production appeared too high to justify statistical comparisons.

\section{Rumen Fluid Sampling and Analyses}

Rumen fluid was collected in wk $1(3.7 \pm 0.2 \mathrm{~d}), 2$ $(8.1 \pm 0.2 \mathrm{~d}), 3(15 \pm 0.2 \mathrm{~d}), 6(35.6 \pm 0.4 \mathrm{~d}), 9(55.9$ $\pm 0.4 \mathrm{~d}), 14(91.1 \pm 0.6 \mathrm{~d}), 18(119.9 \mathrm{~d} \pm 0.4 \mathrm{~d})$, and $22(148 \pm 0.5 \mathrm{~d})$ by using an esophageal tubing system, whereas animals equipped with a rumen cannula were sampled in wk 14, 18, and 22 via the cannula by inserting the tubing into the saccus ventralis of the rumen. Approximately $30 \mathrm{~mL}$ of rumen fluid was drawn via a syringe attached to the tubing. In case sampling was carried out via the esophagus, the first retrieved $\sim 20$ $\mathrm{mL}$ of rumen fluid was discarded, to avoid contamination with saliva. The fluid was centrifuged at $4^{\circ} \mathrm{C}$ for $10 \mathrm{~min}$ at $3,360 \times \mathrm{g}$. The supernatant was removed and stored on ice. For analysis of rumen fluid VFA concentrations, $1 \mathrm{~mL}$ of $0.5 \%$ isocaproic acid was added as internal standard to $2.5 \mathrm{~mL}$ of supernatant. The resulting mixture was centrifuged at $4^{\circ} \mathrm{C}$ for $10 \mathrm{~min}$ at $13,000 \times g$ and stored at $-20^{\circ} \mathrm{C}$ until analysis. Samples $(1 \mathrm{~mL})$ were acidified with $5 \mu \mathrm{L}$ of $37 \%$ hydrochloric acid and analyzed for VFA using a gas chromatograph with a flame ionization detector (GC-FID, Series 17A, Shimadzu Corp., Kyoto, Japan), equipped with a 25-m $\times 0.25-\mathrm{mm}$ free fatty acid phase column (Roth, Karlsruhe, Germany).

\section{Gastrointestinal Passage Rate and Estimated OM Digestibility}

The gastrointestinal passage rate was measured in parallel to $\mathrm{CH}_{4}$ production measurements (wk 6, 9, 14, and 22). The calves received an oral dose of $2.2 \mathrm{~g}$ of titanium dioxide $\left(\mathrm{TiO}_{2}\right)$ in wk 6 and $9,3 \mathrm{~g}$ in wk 14, and $4 \mathrm{~g}$ in wk 22. The $\mathrm{TiO}_{2}$ powder was suspended in 50 $\mathrm{mL}$ of isotonic saline and administered to the animals by an esophageal tube at $1700 \mathrm{~h}$. On the following $4 \mathrm{~d}$, fecal samples were taken at 0700 and $1700 \mathrm{~h}$ and on $\mathrm{d}$ 5 and 6 only at $0700 \mathrm{~h}$. Samples were stored at $-20^{\circ} \mathrm{C}$ until analysis. To determine $\mathrm{TiO}_{2}$ concentrations, feces samples were thawed and dried at $65^{\circ} \mathrm{C}$ for $72 \mathrm{~h}$ and analyzed using the method described by Brandt and Allam (1987). Whole-digesta mean retention time (MRT) was calculated according to Thielemans et al. (1978):

$$
\operatorname{MRT}(\mathrm{h})=\Sigma\left(\mathrm{t}_{\mathrm{i}} \times \mathrm{dt} \times \mathrm{c}_{\mathrm{i}}\right) / \Sigma\left(\mathrm{dt} \times \mathrm{c}_{\mathrm{i}}\right),
$$

where $t_{i}$ is the time after marker application; dt the time interval represented by marker content, calculated as $\left[\left(t_{i+1}-t_{i}\right)+\left(t_{i}-t_{i-1}\right)\right] / 2$; and $c_{i}$ the fecal marker content at time $\mathrm{i}$.

The OM digestibility was estimated only in the postweaning period. Fecal samples taken in wk 14 and 22 were pooled for every animal, and the $\mathrm{N}$ content was analyzed by a CNS Element Analyzer (Vario Max, Elementar Analysensysteme GmbH, Langenselbold, Germany). Samples were combusted in an oxygen atmosphere at approximately $1,000^{\circ} \mathrm{C}$, and $\mathrm{N}$ content was determined at a thermal conductivity detector. The fecal OM was estimated by ashing the dried fecal samples at $550^{\circ} \mathrm{C}$ for $5 \mathrm{~h}$. Fecal $\mathrm{CP}$ was calculated as $\mathrm{CP}(\mathrm{g} / \mathrm{kg}$ of $\mathrm{OM})=\mathrm{N}(\mathrm{g} / \mathrm{kg}$ of $\mathrm{OM}) \times 6.25$. The diet $\mathrm{OM}$ digestibility was estimated according to Lukas et al. (2005): OM digestibility $(\%)=79.76-$ $107.7 \mathrm{e}^{[-0.01515 \times \text { fecal } \mathrm{CP}(\mathrm{g} / \mathrm{kg} \text { of OM })]}$

\section{Rumen Ultrasonography}

Ultrasonographic examination of the rumen size was conducted in weekly intervals starting in wk 2 , according to Braun et al. (2013). The rumen size was determined at the 11th intercostal space (the anatomic space between the 11th and 12th ribs) using an ultrasound scanner (MicroMaxx UltrasoundSystem, Sonosite Inc., Bothell, WA), equipped with a sector array transducer (MicroMaxx P10, Sonosite Inc.) with a frequency of 8 to $4 \mathrm{MHz}$ and a scan depth of $7.2 \mathrm{~cm}$. The dorsal and ventral visible margins of the rumen were identified, and the distance of each margin to the dorsal midline 
of the animal was measured. The rumen size $(\mathrm{cm})$ was calculated by subtracting the dorsal from the ventral margin of the rumen. Heart girth was measured additionally at every examination and was used to normalize rumen size. Measurements performed on 9 animals in wk 2 were excluded from statistical evaluation because margins of the rumen could not be determined with sufficient certainty.

\section{Reticulorumen Volume Measurement}

In wk $34(34.4 \pm 0.1) 9$ animals from the $10 \%$-MR group (6 thereof rumen cannulated) and 8 from the 20\%-MR group (4 thereof rumen cannulated) were slaughtered. The reticulorumen was removed immediately after slaughter and emptied, and, if the animal was equipped with a cannula, the opening was closed with a double-layer running suture. Reticulorumen volume (L) was determined by filling the reticulorumen with water in a cold-water bath at isobaric pressure according to the method described by Nagel and Piatkowski (1972).

\section{Statistical Analysis}

Statistical analyses were performed using SAS software for Windows, version 9.4 (SAS Institute Inc., Cary, NC). Except for the RRV variables, data were analyzed via repeated measurement analyses of variance using the MIXED procedure in SAS/STAT software. The models contained the fixed factors of feeding group (10\%-MR or $20 \%$-MR), cannula (cannulated or non-cannulated), time, and all interactions, where time was the repeated variable. For DMI (weekly means of daily measures), BW, anatomical measures, and rumen size, with time levels weekly, an autoregressive structure for the block diagonal residual covariance matrix was used in the repeated statement of MIXED. For all remaining variables with the time levels wk $6,9,14$, and 22 , and wk $1,2,3,6,9,14,18$, and 22 , an unstructured type for the block diagonal residual covariance matrix was applied. The ANOVA model for the RRV contained the fixed factor feeding group (10\%-MR or 20\%-MR) and cannula (cannulated or non-cannulated). Least squares means (LSM) and their standard errors (SE) were computed for each fixed effect in the models described above, and all pairwise differences between LSM were tested using the Tukey-Kramer procedure. The SLICE statement of the MIXED procedure was used to perform partitioned analyses of the LSM for all interactions. Effects and differences with $P$-values $<$ 0.05 were considered as significant. Results are stated as least squares means if not declared otherwise.

\section{RESULTS}

\section{Feed Intake and Growth Performance}

Dry matter intake of MR increased over time in both feeding groups until weaning $\left(P_{\text {time }}<0.05\right)$ and was, between wk 2 and 9 , more than twice the amount in the $20 \%$ than in the $10 \%$-MR group $\left(P_{\text {group }}<0.05\right.$; Figure 1a). Dry matter intake of calf starter also increased over time in both groups until the period of reduction $\left(P_{\text {time }}<0.05\right)$ and was higher in the $10 \%$ compared with the $20 \%$-MR group $\left(P_{\text {group }}<0.05\right.$; Figure $\left.1 \mathrm{~b}\right)$. In both groups, DMI of hay increased only until wk 10 and decreased thereafter $\left(P_{\text {time }}<0.05\right)$, whereas the $10 \%$-MR group tended to ingest more hay than the $20 \%$-MR group $\left(P_{\text {group }}<0.10 ;\right.$ Figure $\left.1 c\right)$. Dry matter intake of TMR and of SF increased as well over time in both groups $\left(P_{\text {time }}<0.05\right)$. From wk 12 onward, calves of the 20\%-MR group showed higher DMI of TMR than did their counterparts $\left(P_{\text {group }}<0.05\right.$; Figure $\left.1 \mathrm{~d}\right)$. Dry matter intake of SF was higher in the 10\%-MR group pre-weaning (wk 6 to 10), whereas post-weaning (wk $15,16,18,19,20$, and 23) the 20\%-MR group consumed more DM of SF $(P<0.05$, Tukey-Kramer; Figure 1e). Weekly measured BW, HG, body height, body length, and BCS increased over time in both groups $\left(P_{\text {time }}<\right.$ 0.05 ) but to a higher extent in the $20 \%$-MR than in the $10 \%$-MR group $\left(P_{\text {group }}<0.05\right.$; Figure 2$)$.

\section{$\mathrm{CH}_{4}$ Production, Whole-Digesta MRT, and Estimated OM Digestibility}

In accordance with the different DMI levels of SF, the $10 \%$-MR group showed a higher daily $\mathrm{CH}_{4}$ production pre-weaning in wk $9(P<0.05$, Tukey-Kramer $)$, whereas the 20\%-MR group tended to have higher levels postweaning in wk 14 and $22(P<0.10$, Tukey-Kramer $)$. For both groups daily $\mathrm{CH}_{4}$ production increased over time $\left(P_{\text {time }}<0.05\right.$; Figure 3a). When $\mathrm{CH}_{4}$ production was normalized to BW, values of both groups increased over time $\left(P_{\text {time }}<0.05\right)$ and were higher in the $10 \%$ MR group only before weaning at wk 6 and $9(P<$ 0.05, Tukey-Kramer; Figure 3b). Methane emission per unit of DMI of SF $\left(\mathrm{CH}_{4}\right.$ yield) was not different between groups but changed over time $\left(P_{\text {time }}<0.05\right)$. Specifically, $\mathrm{CH}_{4}$ yield was greater in wk 6 and 9 than in wk 14 and lower in wk 14 than in wk $22(P<0.05$, Tukey-Kramer; Figure 3c).

During the pre-weaning period, mean estimated cumulative $\mathrm{CH}_{4}$ production per calf amounted to $1,612 \mathrm{~L}$ for the $10 \%$-MR and 1,253 L for the 20\%-MR group. Post-weaning 10\%-MR animals produced 6,599 L and 20\%-MR animals produced 7,478 L. Thus, cumula- 

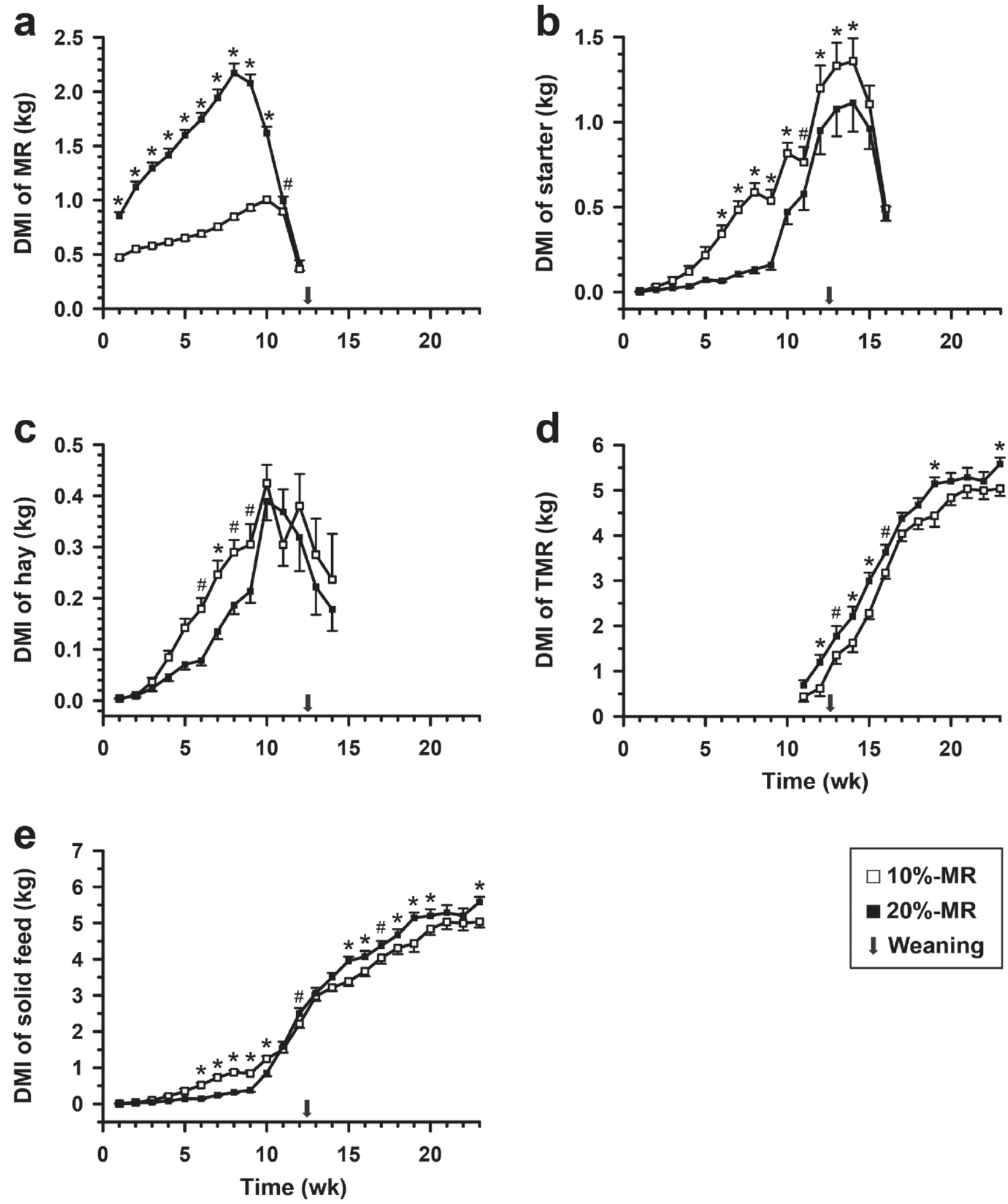

Figure 1. Average daily DMI of milk replacer (MR) starting from d 3, solid feed, starter, hay, and TMR of the calves fed $10 \%(10 \%$-MR, $\square)$ or $20 \%(20 \%$-MR, $\mathbf{n})$ of their BW in MR. Arrows indicate completed weaning. Data are shown as mean $\pm \mathrm{SEM} ;{ }^{*} P<0.05, \# P<0.10$ (Tukey-Kramer). (a) $P_{\text {group }}<0.01, P_{\text {time }}<0.01, P_{\text {group } x \text { time }}<0.01$. (b) $P_{\text {oroup }}<0.01, P_{\text {time }}<0.01, P_{\text {oroup }} \times$ time $=0.14$. (c) $P_{\text {proup }}<0.10, P_{\text {time }}<$ $0.01, P_{\text {group } \times \text { time }}=0.37$. (d) $P_{\text {group }}<0.01, P_{\text {time }}<0.01, P_{\text {group } \times \text { time }}<0.10$. (e) $P_{\text {group }}=0.40, P_{\text {time }}<0.01, P_{\text {group }} \times$ time $<0.01$. $P$-values for cannula, group $\times$ cannula, and group $\times$ cannula $\times$ time are presented in Supplemental Table S3 (https://doi.org/10.3168/jds.2019-17875). 

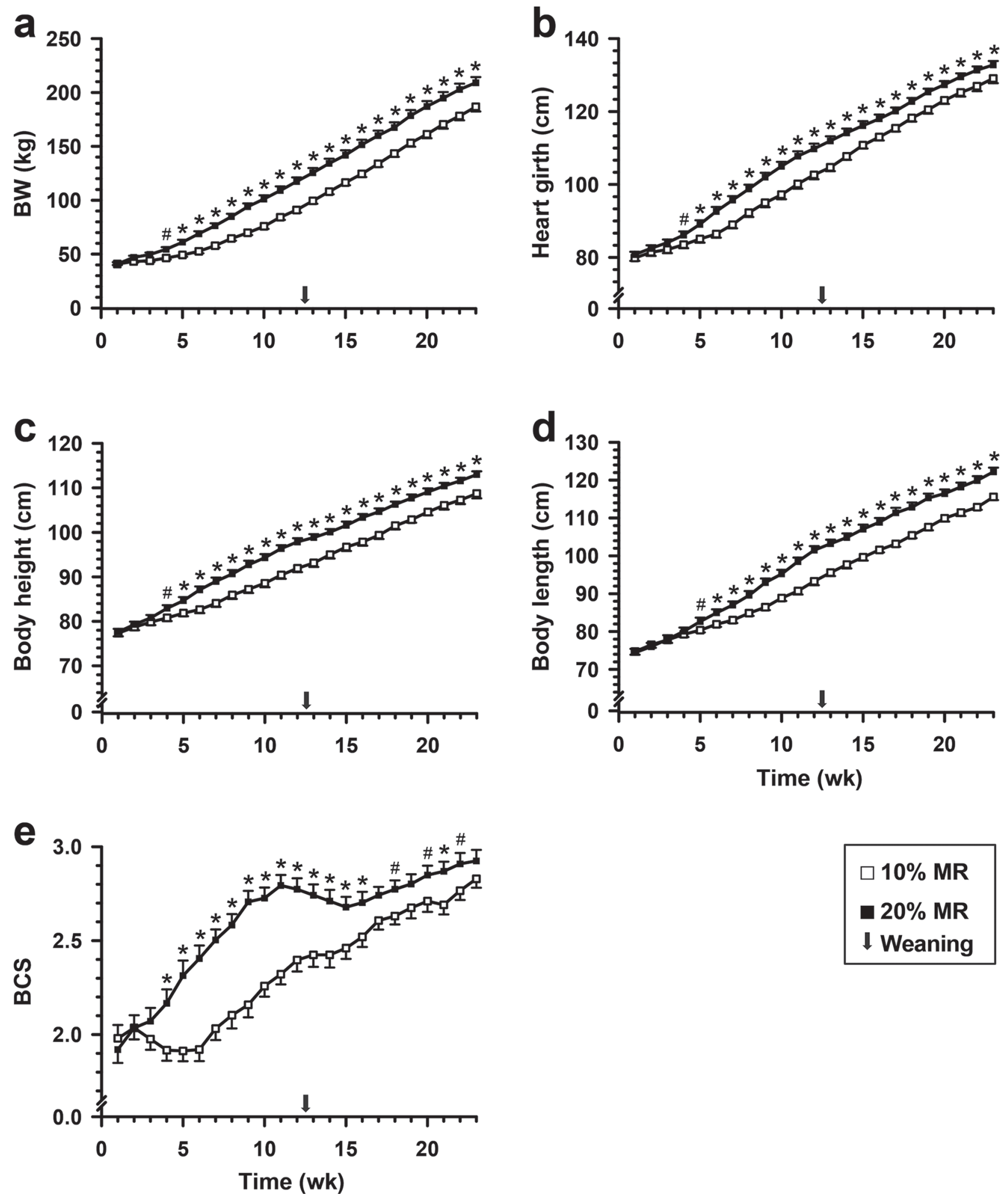

Figure 2. Weekly measured BW, heart girth, body height, body length, and BCS of the calves fed $10 \%$ (10\%-MR, $\square$ ) or $20 \%$ (20\%-MR, 口) of their BW in milk replacer (MR). Arrows indicate completed weaning. Data are shown as mean \pm SEM; ${ }^{*} P<0.05$, \#P<0.10 (TukeyKramer). $P_{\text {group }}<0.01, P_{\text {time }}<0.01, P_{\text {group }} \times$ time $<0.01$. $P$-values for cannula, group $\times$ cannula, and group $\times$ cannula $\times$ time are presented in Supplemental Table S4 (https://doi.org/10.3168/jds.2019-17875). 

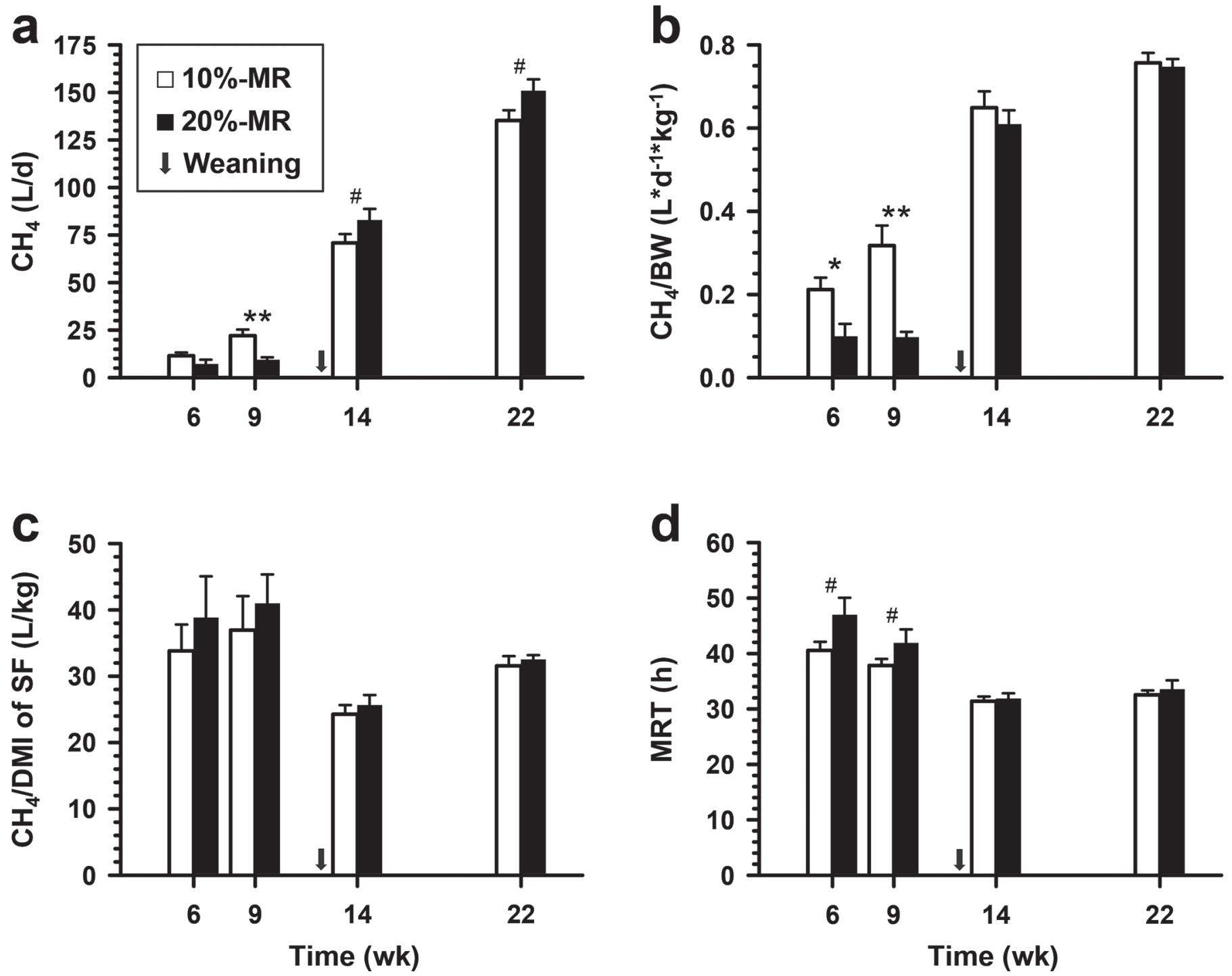

Figure 3. Average daily $\mathrm{CH}_{4}, \mathrm{CH}_{4} / \mathrm{BW}, \mathrm{CH}_{4} / \mathrm{DMI}$ of solid feed (SF), and whole-digesta mean retention time (MRT) at wk 6, 9, 14, and 22 of calves fed $10 \%(10 \%$-MR, $\square)$ or $20 \%(20 \%$-MR, $\mathbf{-})$ of their BW in milk replacer (MR). Arrows indicate completed weaning. Data are shown

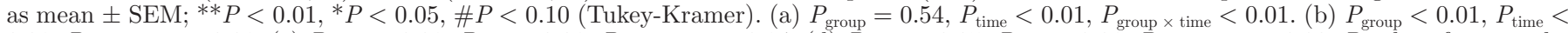

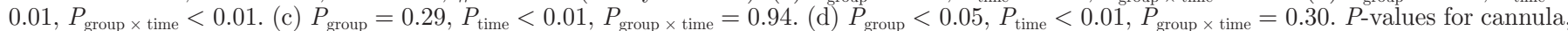
group $\times$ cannula, and group $\times$ cannula $\times$ time are presented in Supplemental Table S5 (https://doi.org/10.3168/jds.2019-17875) .

tive $\mathrm{CH}_{4}$ production until wk 22 amounted to $8,211 \mathrm{~L}$ for the 10\%-MR and 8,732 L for the $20 \%$-MR group. Accordingly, the 20\%-MR group emitted 359 L less pre-weaning but $880 \mathrm{~L}$ more post-weaning, resulting in a surplus of $521 \mathrm{~L} \mathrm{CH}_{4}$ over the entire study period, relative to the $10 \%$-MR group.

Whole-digesta MRT tended to be higher pre-weaning in wk 6 and $9(P<0.10$, Tukey-Kramer $)$ in 20\%-MR fed calves. Levels in both groups declined over time $\left(P_{\text {time }}<0.05\right)$, reaching lower levels post-weaning $(P<$ 0.05, Tukey-Kramer; Figure 3d).

After weaning, estimated OM digestibility decreased from wk 14 to wk $22\left(P_{\text {time }}<0.05\right)$ but was not differ- ent between feeding groups (wk 14: $75.6 \pm 0.29 \%$ and $75.9 \pm 0.29 \%$, wk $22: 74.0 \pm 0.45 \%$ and $74.8 \pm 0.45 \%$ for the $10 \%$ and 20\%-MR group, respectively; $P_{\text {group }}$ $=0.22 ; P$-values for cannula and all interactions are presented in Supplemental Table S7; https://doi.org/ 10.3168/jds.2019-17875).

\section{Rumen Size and RRV}

Weekly measured rumen size increased over time $\left(P_{\text {time }}<0.05\right)$ but was not different among groups, except on 5 time points. The $10 \%$-MR group tended to have higher values in wk $8(P<0.10$, Tukey-Kramer $)$, 

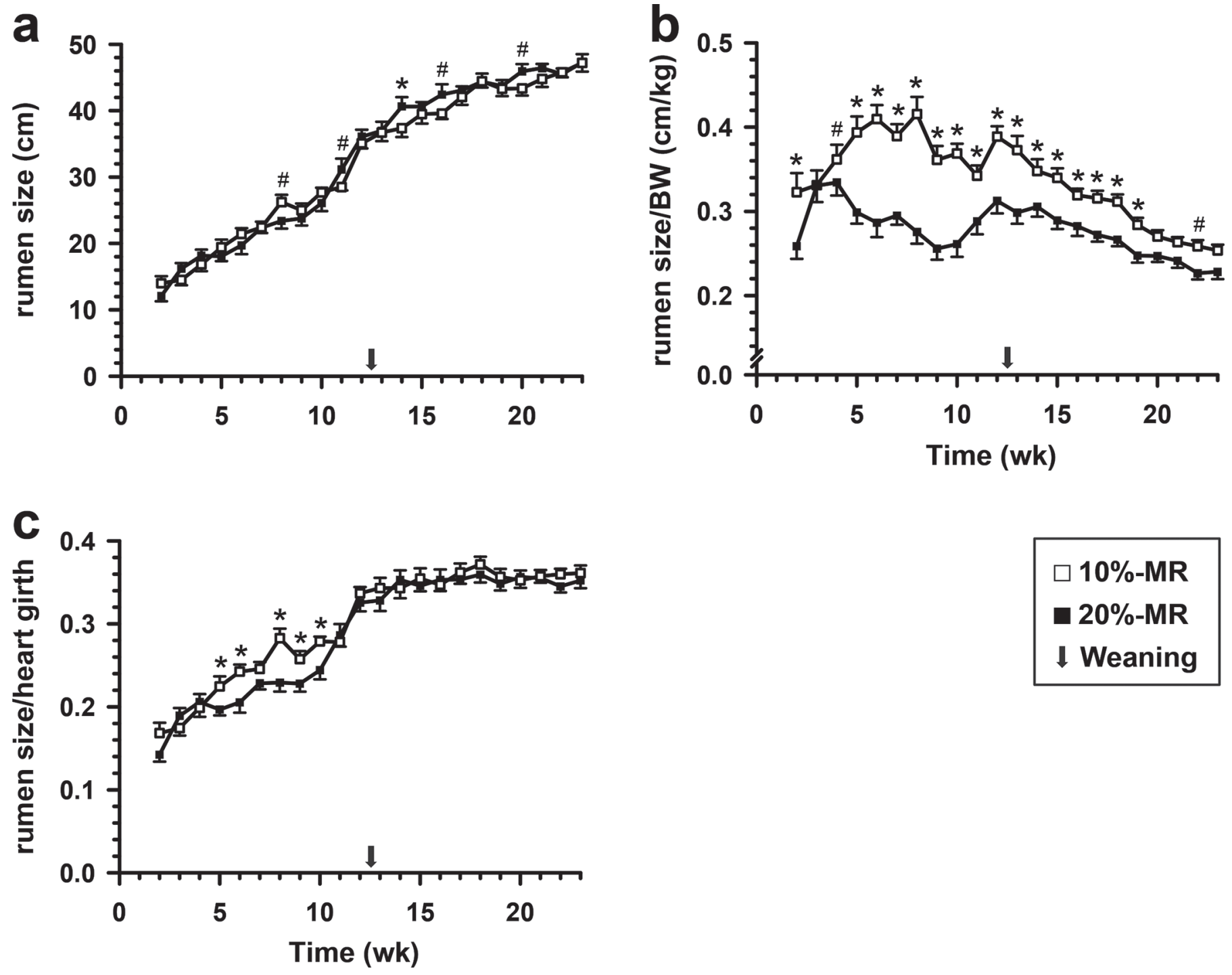

\section{$10 \%-M R$ 20\%-MR $\downarrow$ Weaning}

Figure 4. Weekly measured rumen size, rumen size/BW, and rumen size/heart girth of calves fed 10\% (10\%-MR, $\square)$ or $20 \%$ (20\%-MR, of their BW in milk replacer (MR). Arrows indicate completed weaning. Data are shown as mean \pm SEM; $* P<0.05$, and \#P<0.10 (TukeyKramer). (a) $P_{\text {group }}=0.42, P_{\text {time }}<0.01, P_{\text {group } \times \text { time }}=0.18$. (b) $P_{\text {group }}<0.01, P_{\text {time }}<0.01, P_{\text {group } \times \text { time }}<0.01$. (c) $P_{\text {group }}<0.01, P_{\text {time }}<0.01$, $P_{\text {group }} \times$ time $<0.05$. $P$-values for cannula, group $\times$ cannula, and group $\times$ cannula $\times$ time are presented in Supplemental Table S6 (https://doi $. org $/ 10.3168 / \mathrm{jds} .2019-17875)$.

whereas the $20 \%$-MR group tended to have $(P<0.10)$ or had $(P<0.05)$ higher values in wk 11, 14, 16, and 20 (Tukey-Kramer; Figure 4a). When rumen size was normalized to BW, values were higher for the $10 \%-\mathrm{MR}$ than 20\%-MR group $\left(P_{\text {group }}<0.05\right.$; Figure $\left.4 \mathrm{~b}\right)$. Rumen size normalized to HG increased over time in both

Table 1. Least squares means and pooled standard error (PSE) of reticulorumen volume (RRV), BW, and RRV/BW at wk 34 in calves fed $10 \%(10 \%$-MR, $\mathrm{n}=9)$ or $20 \%(20 \%$-MR, $\mathrm{n}=8)$ of their BW in milk replacer $(\mathrm{MR})$

\begin{tabular}{lcccc}
\hline Item & $10 \%$-MR & $20 \%$-MR & PSE & $P_{\text {group }}{ }^{1}$ \\
\hline RRV (L) & 32.2 & 41.5 & 2.79 & 0.04 \\
BW (kg) & 271.5 & 314.7 & 6.37 & $<0.01$ \\
RRV /BW (L/kg) & 0.12 & 0.13 & 0.01 & 0.31 \\
\hline
\end{tabular}

${ }^{1} P$-value from ANOVA analysis $(P$-values for cannula and group $\times$ cannula are presented in Supplemental Table S8, https://doi.org/10.3168/jds.2019-17875). 
groups $\left(P_{\text {time }}<0.05\right)$ and was higher in the $10 \%$-MR group in wk 5, 6, 8, 9, and $10(P<0.05$, Tukey-Kramer; Figure 4c).

In wk $34, \mathrm{RRV}$ and BW were higher in the $20 \%$-MR group $(P<0.05$, Tukey-Kramer $)$, whereas RRV normalized to BW was not different among groups (Table $1)$.

\section{Ruminal VFA}

All ruminal VFA concentrations, except isovalerate, tended to increase (n-valerate, caproate; $P_{\text {time }}<0.10$ ) or increased (acetate, propionate, isobutyrate, n-butyrate, total VFA; $\left.P_{\text {time }}<0.05\right)$, whereas the acetate/ propionate and (acetate + butyrate)/propionate ratio decreased over time in both feeding groups $\left(P_{\text {time }}<\right.$ 0.05; Supplemental Figure S2, https://doi.org/10.3168/ jds.2019-17875).

Before weaning, the $10 \%$-MR group tended to have higher propionate $(P<0.10$, Tukey-Kramer $)$ and had higher n-butyrate and total VFA $(P<0.05$, TukeyKramer) concentrations in wk 6 (Supplemental Figure S2b, d, and j, https://doi.org/10.3168/jds.2019-17875). Furthermore, propionate concentrations were greater and the acetate/propionate and (acetate + butyrate)/ propionate ratios were lower in wk 9 in $10 \%$-MR calves $(P<0.05$, Tukey-Kramer; Supplemental Figure S2b, h, and i). Post-weaning concentrations of propionate $(P$ $<0.10$, Tukey-Kramer) and acetate and total VFA $(P$ $<0.05$, Tukey-Kramer) in wk 23 tended to be or were higher in the 10\%-MR group (Supplemental Figure S2a, b, and j). For the 20\%-MR group, we only observed a trend of higher concentrations of isobutyrate in wk 3 $(P<0.10$, Tukey-Kramer; Supplemental Figure S2c).

\section{DISCUSSION}

\section{Feed Intake and Growth Performance}

As expected, the elevated MFI led to a lower DMI of SF pre-weaning, which has previously been consistently observed (Khan et al., 2011). In the present study, differences in DMI of SF were more pronounced in starter than in hay intake. This is in line with de Passillé et al. (2011) reporting that milk intake is less negatively correlated with hay than starter intake is. In contrast with the observed higher post-weaning SF intake levels in calves fed an elevated milk or MR feeding intensity, other studies reported no difference post-weaning (Jasper and Weary, 2002; Rosenberger et al., 2017) or even a lower intake 11 to $14 \mathrm{~d}$ after weaning (Hill et al., 2010). A depression of SF intake around weaning in calves fed with high milk or MR feeding intensities, compared with calves fed a lower intensity, is commonly observed (Khan et al., 2011). However, calves fed an elevated milk or MR feeding intensity are less likely to undergo impaired SF intake or ADG around weaning when animals are weaned later (Eckert et al., 2015; Meale et al., 2015) or by implementing gradual weaning programs (Khan et al., 2007b; Sweeney et al., 2010; Omidi-Mirzaei et al., 2015). The prolonged MR feeding period, combined with gradual weaning over 4 wk in the present study, apparently prevented a depression in DMI of SF and even lead to a higher DMI in the 20\%-MR calves post-weaning. We assume that the high DMI in the 20\%-MR calves post-weaning can be explained by their greater BW of $26 \mathrm{~kg}$ in wk 13, which they were able to maintain not only by wk 23 but also until slaughter in wk 34 , with a weight advantage of $43 \mathrm{~kg}$.

Development of anatomical measures was similar to BW development. The $20 \%$-MR calves grew faster pre-weaning, as indicated by their greater body length from wk 6 onward. The advantage in BW, HG, body height, and body length was maintained until the end of the experimental period in wk 23. Similarly, Khan et al. (2007a) and Omidi-Mirzaei et al. (2015) reported that calves fed with an elevated MFI maintained the advantage of body sizes until 14 and $20 \mathrm{~d}$ after weaning, respectively.

Unlike the BW and body sizes development, BCS did not evolve evenly. Pre-weaning, the BCS of $20 \%$-MR calves increased more quickly, and differences were significant from 4 wk onward. However, around and after weaning, BCS dropped markedly in 20\%-MR calves, and so less difference between groups existed from wk 17 onward. Concordantly, Chapman et al. (2016) observed that a higher BW at weaning was accompanied by a higher BCS when feeding a considerably elevated MFI. The slump in BCS around and after weaning in $20 \%$-MR animals indicates that energy intake or energy availability, or both, were compromised. Hill et al. (2016b) showed that calves fed a high MFI had a higher BW and BCS by the end of the pre-weaning period, whereas OM digestibility was compromised around weaning, and BCS in wk 9 post-weaning was comparable to counterparts on a lower MFI. It is commonly observed that various digestibility measures in calves fed a high MFI are reduced post-weaning compared with calves fed a lower MFI (Dennis et al., 2019; Hu et al., 2019). This may have also been the case in our study, without being captured by our general OM digestibility estimation. Moreover, Quigley et al. (2019b) reported 
that cumulative intake of calf starter NFC, which was substantially lower in our 20\%-MR calves pre-weaning, is of crucial importance for full development of NFC and NDF digestibility. Additionally, ME intake per metabolic BW dropped around weaning in 20\%-MR animals below levels of the 10\%-MR group (data not shown). Thus the level of total energy intake might also have been a factor involved in the BCS decline of the 20\%-MR animals. However, we cannot entirely exclude the possibility that the differences observed in BW, BCS, anatomical measures, and intake may be also owed to the different planes of colostrum intake, as discussed previously (Quigley et al., 2017, 2019a).

\section{$\mathrm{CH}_{4}$ Production}

It is commonly accepted that DMI of SF is a main driving factor of $\mathrm{CH}_{4}$ production, at least among adult ruminants (Ramin and Huhtanen, 2013). The DMI of $\mathrm{SF}$ in the $20 \%$-MR calves was found not to be significantly different from $10 \%$-MR calves before wk 6 , and, therefore, $\mathrm{CH}_{4}$ production measured in wk 6 was only numerically lower in 20\%-MR calves. However, differences in DMI of SF increased by wk 9, when $20 \%$-MR calves had significantly lower DMI and, thus, lower $\mathrm{CH}_{4}$ production. Another reason for the lower daily and cumulative $\mathrm{CH}_{4}$ production of $20 \%$-MR calves before weaning may be the higher dietary fat intake in this group, which is in accordance with an earlier study showing that feeding a 1:1 mixture of MR and cream reduced $\mathrm{CH}_{4}$ production of lambs relative to a haybased diet group (Haque et al., 2014). Ruminal drinking can amount to $20 \%$ of ingested MR (Berends et al., 2015), and inhibition of methanogenesis in the rumen by fat is well described (Knapp et al., 2014). Thus, drinking of MR may have led to a substantial passage of dietary fat into the rumen, which was potentially higher in our $20 \%$-MR animals and calves fed cream in the study of Haque et al. (2014). In the latter study, the cream-fed group, which received only a small amount of straw, was compared with a group fed a hay-based diet (Haque et al., 2014). Thus, the lack of substrate in the rumen of the cream-fed group might have been the more relevant factor involved in the reduction of $\mathrm{CH}_{4}$ production.

After weaning, $\mathrm{CH}_{4}$ production tended to be greater in 20\%-MR calves, which can be explained by their higher DMI of SF. The trend of greater $\mathrm{CH}_{4}$ emission post-weaning in 20\%-MR calves also accounts for the 521-L higher cumulative $\mathrm{CH}_{4}$ emission, as estimated for the whole experimental period. However, a high MFI, as applied for veal calves, as an attempt to mitigate $\mathrm{CH}_{4}$ emission seems reasonable because it also enhances live weight gain; thereby calves achieved slaughter weight much more quickly as compared with calves receiving a low MFI (Abdelsamei et al., 2005). Due to the shorter lifetime of veal compared with dairy calves, the high MFI may even decrease lifetime $\mathrm{CH}_{4}$ emission of veal calves. Also, given the fact that an elevated MFI improves long-term productivity of dairy cows (Soberon et al., 2012), a future evaluation of the influence of MFI on lifetime $\mathrm{CH}_{4}$ intensity, expressed as $\mathrm{CH}_{4} / \mathrm{ECM}$, is required.

Methane emission intensity $\left(\mathrm{CH}_{4} / \mathrm{BW}\right)$ was highly influenced by the feeding regimen. The 10\%-MR animals showed considerably higher values pre-weaning, due to their lower BW. The greater rumen size per BW in 10\%-MR calves might also have contributed to higher $\mathrm{CH}_{4}$ emission intensity pre-weaning, as Goopy et al. (2014) found that sheep with a larger rumen have higher $\mathrm{CH}_{4}$ emission but comparable BW (and DMI) relative to counterparts with smaller rumens. Postweaning, when animals were fed the same diet, the influence of the feeding regimen ceased, and no difference in $\mathrm{CH}_{4}$ emission intensity was apparent.

Methane yield $\left(\mathrm{CH}_{4} / \mathrm{DMI}\right.$ of $\left.\mathrm{SF}\right)$ was not different between feeding groups but decreased from pre- to post-weaning. Similarly, MRT decreased over time, as subsequently discussed, which likely accounts for the decrease in $\mathrm{CH}_{4}$ yield. The direct relationship between digesta MRT or ruminal digesta MRT and $\mathrm{CH}_{4}$ yield has been reported previously (Pinares-Patino et al., 2011; Goopy et al., 2014; Huhtanen et al., 2016). For dairy cows, Huhtanen et al. (2016) described an increase in $\mathrm{CH}_{4}$ production by $0.37 \mathrm{~g} / \mathrm{kg}$ of DMI per $\mathrm{h}$ increase in ruminal digesta MRT. However, the increased MRT level pre-weaning in 20\%-MR calves was not reflected by a higher $\mathrm{CH}_{4}$ yield pre-weaning, likely because of the high variability of the latter. It is worth noting that the high MRT pre-weaning results in $\mathrm{CH}_{4}$ yields ranging between 34 to $41 \mathrm{~L} / \mathrm{kg}$. Post-weaning, calves emitted 24 to $33 \mathrm{~L} / \mathrm{kg}$, thereby reaching almost the lower level of adult cattle on a similar diet (30 to $33 \pm 1.3 \mathrm{~L} / \mathrm{kg}$; Bielak et al., 2016). However, we cannot exclude the possibility that the variability in $\mathrm{CH}_{4}$ yield determined in the present study was partially influenced by the change in MR feeding frequency from 4 to 6 meals in the barn to 3 to 4 equal meals in the chambers. Feeding frequency of MR may have affected SF intake, and a change in feeding frequency of SF has been shown to alter protozoa population (Putnam et al., 1961), fermentation patterns in the rumen (Klusmeyer et al., 1990; Shabi et al., 1999), and whole-tract digestibilities (Sutton et al., 1985; Shabi et al., 1999), all of which are factors influencing methanogenesis (Knapp et al., 2014). 


\section{Whole-Digesta MRT and Estimated OM Digestibility}

Previous studies in calves have shown that decreasing MR intake and increasing SF intake are associated with increased fractional passage rate in the rumen (Broesder et al., 1990; Berends et al., 2015) as well as in the lower digestive tract in mature cattle (Colucci et al., 1990). Accordingly, 10\%-MR calves consuming more DM of SF and less MR showed a trend toward lower whole-digesta MRT pre-weaning. This could be further supported by enhanced rumen motility through increased muscularization of the rumen, because roughage intake promotes muscular development (Hamada et al., 1976).

Estimated OM digestibility was not different between feeding groups 1 wk after weaning (wk 14). This result seems to contrast with previous studies describing an impaired OM digestibility within 1 (Terré et al., 2007) or up to 3 wk after weaning (Hill et al., 2016a) of calves fed an elevated MFI. The digestive capacities in the $20 \%$-MR animals in our study were presumably already better adapted to SF, due to the same mechanism preventing the well-known depression in growth and DMI of SF around weaning, as discussed above. Another factor could be the time lag between weaning and start of the digestibility measurement, which, in our study, was $9 \mathrm{~d}$ instead of $2 \mathrm{~d}$ (Terré et al., 2007), providing the animals with more time to adapt to the diet change. The decrease in estimated OM digestibility from wk 14 to wk 22 can be attributed to changes in diet composition. In wk 14, animals consumed a considerable amount of highly digestible starter, whereas in wk 22, the diet consisted solely of TMR. Concerning the methodological approach of OM digestibility estimation by the fecal CP method, it is important to note that increased hindgut fermentation can result in a higher fecal CP content without changes in total-tract OM digestibility (Lukas et al., 2005). Increased hindgut fermentation may have played a role after weaning when SF intake was increasing and MRT decreasing, potentially leading to a higher flow of undigested carbohydrates to the hindgut.

\section{Rumen Size and RRV}

Except for a few weekly measures, total rumen size did not differ between feeding groups. However, to account for the higher growth rate in the $20 \%$-MR calves, data were normalized. The HG appears more appropriate than BW as an anatomical measure, because the former reflects the potential capacity of the abdomen to host the rumen and is less influenced by body condition of the animal. Rumen size normalized to $\mathrm{HG}$ was mostly greater in the $10 \%$-MR group between wk
5 and 10, which is in accordance with the higher SF intake levels from wk 6 to 10. Previous research has shown that expansion of the rumen is stimulated by structured feed, in particular hay (Harrison et al., 1960; Stobo et al., 1966) but also SF in general (Warner et al., 1956; Tamate et al., 1962). Once milk feeding intensity during step-down was on a similar level in wk 11, the formerly higher SF intake of $10 \%$-MR calves was no longer apparent, and, at the same time, differences in rumen size/HG ceased. In contrast, group differences in rumen size per BW persisted post-weaning, although they declined after wk 10 . This post-weaning difference is likely caused by the normalization to BW, as the $20 \%$-MR animals had not only a higher BW and larger frame size but also a higher body condition. Thus it seems that BW as an anatomical measure is particularly affected by body condition and not only by frame size and HG. According to the higher SF intake post-weaning, we expected a larger rumen size in the $20 \%$-MR calves. However, we found only weekly trends for a larger rumen in these animals. The evaluation of rumen size by our 1-dimensional measurement seems limited, particularly when animals became larger and the difference in SF intake in relation to body size decreased over time. Therefore we used a volumetric measurement after slaughter in wk 34 . We observed a higher RRV in 20\%-MR animals, but as those animals were also heavier, the RRV per BW did not differ between groups. A positive correlation between rumen volume and BW in mature dairy cows was previously observed by Nagel and Piatkowski (1972). Our data suggest that the effect of dietary treatment on rumen size and growth occurs only pre-weaning, whereas postweaning, when animals were fed the same diet, rumen size becomes more a function of body size.

\section{Ruminal VFA}

Increase of VFA concentrations with increasing SF intake in dairy calves has previously been reported (Khan et al., 2016). Accordingly, higher starter or SF intake in calves fed a low MFI led to higher VFA concentrations in the rumen pre-weaning, which agrees with previous findings by Khan et al. (2007a) and de Paula et al. (2017). Also, a greater rumen size has been discussed as diluting VFA concentrations (Rey et al., 2012), but we did not observe differences in total rumen size pre-weaning, indicating that the sole source of higher VFA concentrations in 10\%-MR calves was SF intake. Consumption of high-concentrate diets results in higher ruminal propionate concentrations and a lower ratio of acetate to propionate (Sawal and Kurar, 1998), which explains the higher ruminal propionate concentration and lower acetate-to-propionate ratio in 
wh 9 in 10\%-MR animals, whose concentrate intake was notably higher than that of $20 \%$-MR calves in this week. The observed high acetate-to-propionate ratio in very young calves, and its sharp decrease in the first day of life, is comparable to data obtained by Rey et al. (2012).

The 10\%-MR group further revealed higher concentrations of single VFA in wk 22, which cannot be attributed to a higher SF intake. However, intake levels increased more strongly from wk 18 to 22 in $10 \%$ compared with $20 \%$-MR calves.

\section{Effect of Cannulation}

The effect of cannulation has been reported to have no or only temporary adverse effects on the performance of calves (Sissons and Smith, 1982; Kristensen et al., 2010). We evaluated a potential effect of rumen cannulation by including it as a fixed factor and observed impairment of BW and anatomical measures. Furthermore, intake of MR was lower in cannulated animals. These differences occurred particularly between cannulated and non-cannulated animals of the $20 \%$-MR group. This impaired performance may be attributed to increased tissue damage due to the larger cannula (35-mm o.d.), whereas the smaller cannula (25-mm o.d.) applied by Kristensen et al. (2010) did not affect performance. In the present study, the decrease in MR intake among animals cannulated at $18 \mathrm{~d}$ was apparent only from wk 6 onward, and anatomical measures and BW were lower only after wk 7 . Thus, the effects of cannulation seem to be delayed, again particularly in animals fed a high MFI. This effect may have not observed by Kristensen et al. (2010), who fed calves a comparably low MFI, implanted the cannula at the age of $10 \mathrm{~d}$, and slaughtered calves at the age of 42 or $43 \mathrm{~d}$.

The influence of cannulation on starter and TMR intake is difficult to explain. Around the time of weaning, rumen-cannulated animals preferred starter over TMR, compared with non-cannulated animals, whereas total DMI of SF remained on equal levels. We observed the same feed preferences in the non-cannulated 10\%MR animals. Because MR intake was lower in the $10 \%$-MR and in cannulated $20 \%$-MR animals than in non-cannulated 20\%-MR animals, a higher proportion of energy requirements needed to be covered by solid feed, which may have stimulated starter intake in those animals. However, rumen cannulation can alter rumen environment, microbial communities, and fermentative function (Moate et al., 2013; Wang et al., 2018; Wang et al., 2019) and thereby may also have affected mechanisms of feed intake regulation. The decreased DMI of TMR and SF in cannulated animals in wk 20 to 22 can be explained by their considerably lower weight, amounting to a difference of $16 \mathrm{~kg}$ in wk 23 compared with non-cannulated animals. Likewise, the influence on total $\mathrm{CH}_{4}$ production can be attributed to lower BW and feed intake levels in these animals. The cannula $\times$ time interaction in $\mathrm{CH}_{4}$ yield was caused by a lower $\mathrm{CH}_{4}$ yield among cannulated animals in wk 14, as indicated by their higher concentrate intakes in this week and the fact that dietary concentrate level and $\mathrm{CH}_{4}$ yield are inversely related (Aguerre et al., 2011).

Hirayama and Katoh (2005) reported impaired rumen motility and decreased passage rate in adult goats with a cannula of 50-mm o.d., compared with a cannula of 26-mm o.d. In contrast, our cannulated calves and the 10\%-MR non-cannulated animals had decreased MRT in wk 9. Other factors than changes in rumen motility are likely responsible for this effect, primarily those related to reduced MR intake and a higher proportion of SF to MR intake in cannulated animals.

\section{CONCLUSIONS}

A higher MFI reduces methane emission intensity $\left(\mathrm{CH}_{4} / \mathrm{BW}\right)$ in the pre-weaning period, and this effect was due to both greater $\mathrm{BW}$ and lower $\mathrm{CH}_{4}$ production, although whole-digesta MRT tended to be higher compared with calves fed a lower MFI. After weaning, animals fed an elevated MFI had higher DMI and frame size and tended to have higher total $\mathrm{CH}_{4}$ emission, but $\mathrm{CH}_{4}$ yield $\left(\mathrm{CH}_{4} /\right.$ DMI of solid feed $)$ and estimated $\mathrm{OM}$ digestibility were not affected by MFI applied preweaning. However, rumen size normalized to HG, total $\mathrm{CH}_{4}$ emission, and $\mathrm{CH}_{4}$ emission intensity were lower pre-weaning among calves fed an elevated MFI. This effect can be used to reduce $\mathrm{CH}_{4}$ emission from calves pre-weaning by feeding higher planes of MR and potentially by prolonging the milk-feeding period, as applied in veal calves. However, a higher MFI pre-weaning results in a trend of higher $\mathrm{CH}_{4}$ emissions post-weaning, offsetting the beneficial effect of reduced $\mathrm{CH}_{4}$ emissions pre-weaning in a few weeks. Therefore, the proportion of methane emission that can be reduced by an intensive milk-feeding regimen pre-weaning is fairly small in the context of lifetime emissions from dairy cattle. On the other hand, the higher $\mathrm{CH}_{4}$ emissions resulting from feeding a high MFI may be outweighed by higher lifetime milk productivity and lower $\mathrm{CH}_{4}$ intensity, but this assumption needs to be confirmed in future studies.

\section{ACKNOWLEDGMENTS}

We gratefully thank H. Brandt, C. Arlt, R. Fürstenberg, V. Tesch, E.-A. Paetow, M. Gnott, J. Rischewski, C. Mueller, and the staff at the "Tiertechnikum" and the Experimental Animal Facility Cattle at the Leibniz 
Institute for Farm Animal Biology, Dummerstorf, Germany, for assistance in respiration chamber measurements, cannula manufacturing, animal care and handling, sample collection, and sample preparation. This work was conducted in the framework of the FACCEJPI program and financially supported by the German Federal Ministry of Food and Agriculture (BMEL) through the Federal Office for Agriculture and Food (BLE; Bonn, Germany), grant number 2814ERA04A. The publication of this article was funded by the Open Access Fund of the Leibniz Institute for Farm Animal Biology. The authors have stated no conflicts of interest.

\section{REFERENCES}

Abdelsamei, A. H., D. G. Fox, L. O. Tedeschi, M. L. Thonney, D. J. Ketchen, and J. R. Stouffer. 2005. The effect of milk intake on forage intake and growth of nursing calves. J. Anim. Sci. 83:940-947. https://doi.org/10.2527/2005.834940x.

Abecia, L., A. I. Martin-Garcia, G. Martinez, C. J. Newbold, and D. R. Yáñez-Ruiz. 2013. Nutritional intervention in early life to manipulate rumen microbial colonization and methane output by kid goats postweaning. J. Anim. Sci. 91:4832-4840. https://doi.org/10 $.2527 /$ jas.2012-6142.

Aguerre, M. J., M. A. Wattiaux, J. M. Powell, G. A. Broderick, and C. Arndt. 2011. Effect of forage-to-concentrate ratio in dairy cow diets on emission of methane, carbon dioxide, and ammonia, lactation performance, and manure excretion. J. Dairy Sci. 94:30813093. https://doi.org/10.3168/jds.2010-4011.

Berends, H., J. J. G. C. van den Borne, N. Stockhofe-Zurwieden, M. S. Gilbert, T. Zandstra, W. F. Pellikaan, C. G. van Reenen, E. A. M. Bokkers, and W. J. J. Gerrits. 2015. Effects of solid feed level and roughage-to-concentrate ratio on ruminal drinking and passage kinetics of milk replacer, concentrates, and roughage in veal calves. J. Dairy Sci. 98:5621-5629. https://doi.org/10.3168/ jds.2015-9367.

Bielak, A., M. Derno, A. Tuchscherer, H. M. Hammon, A. Susenbeth, and B. Kuhla. 2016. Body fat mobilization in early lactation influences methane production of dairy cows. Sci. Rep. 6:28135. https: //doi.org/10.1038/srep28135.

Brandt, M., and S. M. Allam. 1987. Analytik von $\mathrm{TiO}_{2}$ im Darminhalt und Kot nach Kjeldahlaufschluß (Analysis of $\mathrm{TiO}_{2}$ in digesta and feces after Kjeldahl digestion.). Pages 453-454 in Proc. Workshop zu Problemen der Verdauungsphysiologie beim Wiederkäuer (Problems of Digestive Physiology in Ruminants; Rostock, 16.17.1.1986). S. Poppe, ed. Arch. Anim. Nutr. 37:451-466. https:// doi.org/10.1080/17450398709425369.

Braun, U., S. Krüger, and M. Hassig. 2013. Ultrasonographic examination of the reticulum, rumen, omasum and abomasum during the first 100 days of life in calves. Res. Vet. Sci. 95:326-333. https:// doi.org/10.1016/j.rvsc.2013.03.019.

Broesder, J. T., M. B. Judkins, L. J. Krysl, S. A. Gunter, and R. K. Barton. 1990. Thirty or sixty percent milk replacer reduction for calves: Effects on alfalfa hay intake and digestibility, digestive kinetics and ruminal fermentation. J. Anim. Sci. 68:2974-2985. https://doi.org/10.2527/1990.6892974x.

Chapman, C. E., P. S. Erickson, J. D. Quigley, T. M. Hill, H. G. Bateman II, F. X. Suarez-Mena, and R. L. Schlotterbeck. 2016. Effect of milk replacer program on calf performance and digestion of nutrients with age of the dairy calf. J. Dairy Sci. 99:2740-2747. https://doi.org/10.3168/jds.2015-10372.

Colucci, P. E., G. K. Macleod, W. L. Grovum, I. McMillan, and D. J. Barney. 1990. Digesta kinetics in sheep and cattle fed diets with different forage to concentrate ratios at high and low intakes. J. Dairy Sci. 73:2143-2156. https://doi.org/10.3168/jds.S0022 $-0302(90) 78895-9$. de Passillé, A. M., T. F. Borderas, and J. Rushen. 2011. Weaning age of calves fed a high milk allowance by automated feeders: Effects on feed, water, and energy intake, behavioral signs of hunger, and weight gains. J. Dairy Sci. 94:1401-1408. https://doi.org/10.3168/ jds.2010-3441.

de Paula, M. R., C. E. Oltramari, J. T. Silva, M. P. C. Gallo, G. B. Mourao, and C. M. M. Bittar. 2017. Intensive liquid feeding of dairy calves with a medium crude protein milk replacer: Effects on performance, rumen, and blood parameters. J. Dairy Sci. 100:4448-4456. https://doi.org/10.3168/jds.2016-10859.

Dennis, T. S., F. X. Suarez-Mena, W. Hu, T. M. Hill, J. D. Quigley, and R. L. Schlotterbeck. 2019. Effects of milk replacer feeding rate and long-term antibiotic inclusion in milk replacer on performance and nutrient digestibility of Holstein dairy calves up to 4 months of age. J. Dairy Sci. 102:2094-2102. https://doi.org/10.3168/jds .2018-15652.

Derno, M., H. G. Elsner, E. A. Paetow, H. Scholze, and M. Schweigel. 2009. Technical note: A new facility for continuous respiration measurements in lactating cows. J. Dairy Sci. 92:2804-2808. https: //doi.org/10.3168/jds.2008-1839.

Eckert, E., H. E. Brown, K. E. Leslie, T. J. DeVries, and M. A. Steele. 2015. Weaning age affects growth, feed intake, gastrointestinal development, and behavior in Holstein calves fed an elevated plane of nutrition during the preweaning stage. J. Dairy Sci. 98:6315-6326. https://doi.org/10.3168/jds.2014-9062.

Edmonson, A. J., I. J. Lean, L. D. Weaver, T. Farver, and G. Webster. 1989. A body condition scoring chart for Holstein dairy cows. J. Dairy Sci. 72:68-78. https://doi.org/10.3168/jds.S0022 -0302(89)79081-0.

Gerber, P. J., H. Steinfeld, B. Henderson, A. Mottet, C. Opio, J. Dijkman, A. Falcucci, and G. Tempio. 2013. Tackling Climate Change Through Livestock-A Global Assessment of Emissions and Mitigation Opportunities. Food and Agriculture Organization of the United Nations (FAO), Rome, Italy.

Goopy, J. P., A. Donaldson, R. Hegarty, P. E. Vercoe, F. Haynes, M. Barnett, and V. H. Oddy. 2014. Low-methane yield sheep have smaller rumens and shorter rumen retention time. Br. J. Nutr. 111:578-585. https://doi.org/10.1017/S0007114513002936.

Guan, H., K. M. Wittenberg, K. H. Ominski, and D. O. Krause. 2006. Efficacy of ionophores in cattle diets for mitigation of enteric methane. J. Anim. Sci. 84:1896-1906. https://doi.org/10.2527/jas .2005-652.

Hamada, T., S. Maeda, and K. Kameoka. 1976. Factors influencing growth of rumen, liver, and other organs in kids weaned from milk replacers to solid foods. J. Dairy Sci. 59:1110-1118. https://doi .org/10.3168/jds.S0022-0302(76)84330-5.

Haque, M. N., M. Roggenbuck, P. Khanal, M. O. Nielsen, and J. Madsen. 2014. Development of methane emission from lambs fed milk replacer and cream for a prolonged period. Anim. Feed Sci. Technol. 198:38-48. https://doi.org/10.1016/j.anifeedsci.2014.09.002.

Harrison, H. N., R. G. Warner, E. G. Sander, and J. K. Loosli. 1960. Changes in the tissue and volume of the stomachs of calves following the removal of dry feed or consumption of inert bulk. J. Dairy Sci. 43:1301-1312. https://doi.org/10.3168/jds.S0022 -0302(60)90317-9.

Hill, T. M., H. G. Bateman II, J. M. Aldrich, and R. L. Schlotterbeck. 2010. Effect of milk replacer program on digestion of nutrients in dairy calves. J. Dairy Sci. 93:1105-1115. https://doi.org/10.3168/ jds.2009-2458.

Hill, T. M., J. D. Quigley, H. G. Bateman II, F. X. Suarez-Mena, T. S. Dennis, and R. L. Schlotterbeck. 2016a. Effect of milk replacer program on calf performance and digestion of nutrients in dairy calves to 4 months of age. J. Dairy Sci. 99:8103-8110. https://doi .org/10.3168/jds.2016-11239.

Hill, T. M., J. D. Quigley, F. X. Suarez-Mena, H. G. Bateman II, and R. L. Schlotterbeck. 2016b. Effect of milk replacer feeding rate and functional fatty acids on dairy calf performance and digestion of nutrients. J. Dairy Sci. 99:6352-6361. https://doi.org/10.3168/ jds.2015-10812.

Hirayama, T., and K. Katoh. 2005. Effects of fistula size on rumen internal pressure and passage rate of feed in goats. Small Rumin. 
Res. 56:277-280. https://doi.org/10.1016/j.smallrumres.2004.06 .004 .

Hu, W., T. M. Hill, T. S. Dennis, F. X. Suarez-Mena, J. D. Quigley, and R. L. Schlotterbeck. 2019. Intake, nutrient digestibility, and growth performance of Holstein dairy calves consuming a milk replacer at moderate or high feeding rates. J. Dairy Sci. 102:79177926. https://doi.org/10.3168/jds.2019-16282.

Huhtanen, P., M. Ramin, and E. H. Cabezas-Garcia. 2016. Effects of ruminal digesta retention time on methane emissions: A modelling approach. Anim. Prod. Sci. 56:501-506. https://doi.org/10.1071/ AN15507.

Jasper, J., and D. M. Weary. 2002. Effects of ad libitum milk intake on dairy calves. J. Dairy Sci. 85:3054-3058. https://doi.org/10.3168/ jds.S0022-0302(02)74391-9.

Jentsch, W., M. Schweigel, F. Weissbach, H. Scholze, W. Pitroff, and M. Derno. 2007. Methane production in cattle calculated by the nutrient composition of the diet. Arch. Anim. Nutr. 61:10-19. https://doi.org/10.1080/17450390601106580.

Khan, M. A., A. Bach, D. M. Weary, and M. A. G. von Keyserlingk. 2016. Invited review: Transitioning from milk to solid feed in dairy heifers. J. Dairy Sci. 99:885-902. https://doi.org/10.3168/jds.2015 -9975 .

Khan, M. A., H. J. Lee, W. S. Lee, H. S. Kim, K. S. Ki, T. Y. Hur, G. H. Suh, S. J. Kang, and Y. J. Choi. 2007a. Structural growth, rumen development, and metabolic and immune responses of Holstein male calves fed milk through step-down and conventional methods. J. Dairy Sci. 90:3376-3387. https://doi.org/10.3168/jds 2007-0104.

Khan, M. A., H. J. Lee, W. S. Lee, H. S. Kim, S. B. Kim, K. S. Ki, J. K. Ha, H. G. Lee, and Y. J. Choi. 2007b. Pre- and postweaning performance of Holstein female calves fed milk through step-down and conventional methods. J. Dairy Sci. 90:876-885. https://doi .org/10.3168/jds.S0022-0302(07)71571-0.

Khan, M. A., D. M. Weary, and M. A. G. von Keyserlingk. 2011. Invited review: Effects of milk ration on solid feed intake, weaning, and performance in dairy heifers. J. Dairy Sci. 94:1071-1081. https://doi.org/10.3168/jds.2010-3733.

Klusmeyer, T. H., M. R. Cameron, G. C. McCoy, and J. H. Clark. 1990. Effects of feed processing and frequency of feeding on ruminal fermentation, milk production, and milk composition. J. Dairy Sci. 73:3538-3543. https://doi.org/10.3168/jds.S0022 -0302(90)79053-4.

Knapp, J. R., G. L. Laur, P. A. Vadas, W. P. Weiss, and J. M. Tricarico. 2014. Invited review: Enteric methane in dairy cattle production: Quantifying the opportunities and impact of reducing emissions. J. Dairy Sci. 97:3231-3261. https://doi.org/10.3168/jds .2013-7234.

Kristensen, N. B., M. Engbæk, M. Vestergaard, and D. L. Harmon. 2010. Technical note: Ruminal cannulation technique in young Holstein calves: Effects of cannulation on feed intake, body weight gain, and ruminal development at six weeks of age. J. Dairy Sci. 93:737-742. https://doi.org/10.3168/jds.2009-2488.

Lukas, M., K. H. Südekum, G. Rave, K. Friedel, and A. Susenbeth. 2005. Relationship between fecal crude protein concentration and diet organic matter digestibility in cattle. J. Anim. Sci. 83:13321344. https://doi.org/10.2527/2005.8361332x.

Meale, S. J., L. N. Leal, J. Martín-Tereso, and M. A. Steele. 2015. Delayed weaning of Holstein bull calves fed an elevated plane of nutrition impacts feed intake, growth and potential markers of gastrointestinal development. Anim. Feed Sci. Technol. 209:268-273. https://doi.org/10.1016/j.anifeedsci.2015.08.008.

Metzner, M., W. Heuwieser, and W. Klee. 1993. Die Beurteilung der Körperkondition (Body condition scoring) im Herdenmanagement. Prakt. Tierarzt 74:991-998.

Moate, P. J., S. R. O. Williams, M. H. Deighton, J. L. Jacobs, and W. J. Wales. 2013. Influence of rumen cannulation on feed intake, milk production, enteric methane production and composition of rumen headspace gas. In Proc. 5th Greenhouse Gases and Animal Agriculture Conference (GGAA 2013). Adv. Anim. Biosci. 4:423.

Myhre, G., D. Shindell, F.-M. Bréon, W. Collins, J. Fuglestvedt, J. Huang, D. Koch, J.-F. Lamarque, D. Lee, B. Mendoza, T. Na- kajima, A. Robock, G. Stephens, T. Takemura, and H. Zhang. 2013. Anthropogenic and natural radiative forcing. Pages 659-740 in Climate Change 2013: The Physical Science Basis. Contribution of Working Group I to the Fifth Assessment Report of the Intergovernmental Panel on Climate Change. T. F. Stocker, D. Qin, G.-K. Plattner, M. Tignor, S. K. Allen, J. Boschung, A. Nauels, Y. Xia, V. Bex, and P. M. Midgley, ed. Cambridge University Press, Cambridge, UK.

Nagel, S., and B. Piatkowski. 1972. Untersuchungen des Pansenvolumens und der Pansenmasse von Milchkühen (Examination of rumen volume and rumen weight in dairy cows). Arch. Anim. Nutr. 22:449-456. https://doi.org/10.1080/17450397209424538.

Omidi-Mirzaei, H., M. Khorvash, G. R. Ghorbani, B. Moshiri, M. Mirzaei, A. Pezeshki, and M. H. Ghaffari. 2015. Effects of the step-up/step-down and step-down milk feeding procedures on the performance, structural growth, and blood metabolites of Holstein dairy calves. J. Dairy Sci. 98:7975-7981. https://doi.org/10.3168/ jds.2014-9260.

Pinares-Patino, C., S. H. Ebrahimi, J. McEwan, K. Dodds, H. Clark, and D. Luo. 2011. Is rumen retention time implicated in sheep differences in methane emission? Pages 219-222 in Proc. New Zealand Society of Animal Production, Invercargill, NZ. https://doi .org/10.13140/2.1.3309.5043.

Putnam, P. A., J. Gutierrez, and R. E. Davis. 1961. Effects of frequency of feeding upon rumen volatile acids, protozoal population, and weight gains in Angus Heifer calves. J. Dairy Sci. 44:1364-1365. https://doi.org/10.3168/jds.S0022-0302(61)89889-5.

Quigley, J. D., L. Deikun, T. M. Hill, F. X. Suarez-Mena, T. S. Dennis, and W. Hu. 2019a. Effects of colostrum and milk replacer feeding rates on intake, growth, and digestibility in calves. J. Dairy Sci. 102:11016-11025. https://doi.org/10.3168/jds.2019-16682.

Quigley, J. D., T. M. Hill, L. L. Deikun, and R. L. Schlotterbeck. 2017. Effects of amount of colostrum replacer, amount of milk replacer, and housing cleanliness on health, growth, and intake of Holstein calves to 8 weeks of age. J. Dairy Sci. 100:9177-9185. https://doi .org/10.3168/jds.2017-12784.

Quigley, J. D., W. Hu, J. R. Knapp, T. S. Dennis, F. X. Suarez-Mena, and T. M. Hill. 2019b. Estimates of calf starter energy affected by consumption of nutrients. 2. Effect of changing digestion on energy content in calf starters. J. Dairy Sci. 102:2242-2253. https://doi .org/10.3168/jds.2018-15354.

Ramin, M., and P. Huhtanen. 2013. Development of equations for predicting methane emissions from ruminants. J. Dairy Sci. 96:24762493. https://doi.org/10.3168/jds.2012-6095.

Raschke, K. 2007. Erstellung eines Schemas zur Beurteilung der Körperkondition von Kälbern der Rassen "Deutsches Fleckvieh" und "Holstein Friesian" (Development of a protocol to assess the body condition of German Simmental and Holstein calves). DVM Thesis. Faculty of Veterinary Medicine Ludwig Maximilian Univ., Munich, Germany.

Rey, M., F. Enjalbert, and V. Monteils. 2012. Establishment of ruminal enzyme activities and fermentation capacity in dairy calves from birth through weaning. J. Dairy Sci. 95:1500-1512. https:// doi.org/10.3168/jds.2011-4902.

Rogelj, J., D. Shindell, K. Jiang, S. Fifita, P. Forster, V. Ginzburg, C. Handa, H. Kheshgi, S. Kobayashi, E. Kriegler, L. Mundaca, R. Séférian, and M. V. Vilariño. 2018. Mitigation pathways compatible with $1.5^{\circ} \mathrm{C}$ in the context of sustainable development. Pages 93-174 in Global Warming of $1.5^{\circ} \mathrm{C}$ : An IPCC Special Report on the Impacts of Global Warming of $1.5^{\circ} \mathrm{C}$ Above Pre-Industrial Levels and Related Global Greenhouse Gas Emission Pathways, in the Context of Strengthening the Global Response to the Threat of Climate Change, Sustainable Development, and Efforts to Eradicate Poverty. V. Masson-Delmotte, P. Zhai, H.-O. Pörtner, D. Roberts, J. Skea, P. R. Shukla, A. Pirani, W. Moufouma-Okia, C. Péan, R. Pidcock, S. Connors, J. B. R. Matthews, Y. Chen, X. Zhou, M. I. Gomis, E. Lonnoy, T. Maycock, M. Tignor, and T. Waterfield, ed. In press.

Rosenberger, K., J. H. C. Costa, H. W. Neave, M. A. G. von Keyserlingk, and D. M. Weary. 2017. The effect of milk allowance on be- 
havior and weight gains in dairy calves. J. Dairy Sci. 100:504-512. https://doi.org/10.3168/jds.2016-11195.

Sawal, R. K., and C. K. Kurar. 1998. Milk yield and its fat content as a affected by dietary factors: A review. Asian-Australas. J. Anim. Sci. 11:217-233. https://doi.org/10.5713/ajas.1998.217.

Shabi, Z., I. Bruckental, S. Zamwell, H. Tagari, and A. Arieli. 1999. Effects of extrusion of grain and feeding frequency on rumen fermentation, nutrient digestibility, and milk yield and composition in dairy cows. J. Dairy Sci. 82:1252-1260. https://doi.org/10.3168/ jds.S0022-0302(99)75348-8.

Silva, A. L., T. J. DeVries, L. O. Tedeschi, and M. I. Marcondes. 2019. Development of equations, based on milk intake, to predict starter feed intake of preweaned dairy calves. Animal 13:83-89. https:// doi.org/10.1017/S1751731118000666.

Sissons, J. W., and R. H. Smith. 1982. Effect of duodenal cannulation on abomasal emptying and secretion in the preruminant calf. J. Physiol. 322:409-417. https://doi.org/10.1113/jphysiol.1982 .sp014045.

Soberon, F., E. Raffrenato, R. W. Everett, and M. E. Van Amburgh. 2012. Preweaning milk replacer intake and effects on long-term productivity of dairy calves. J. Dairy Sci. 95:783-793. https://doi .org/10.3168/jds.2011-4391.

Stobo, I. J. F., J. H. B. Roy, and H. J. Gaston. 1966. Rumen development in the calf. Br. J. Nutr. 20:171-188. https://doi.org/10.1079/ BJN19660021

Sutton, J. D., W. H. Broster, D. J. Napper, and J. W. Siviter. 1985. Feeding frequency for lactating cows: Effects on digestion, milk production and energy utilization. Br. J. Nutr. 53:117-130. https: //doi.org/10.1079/BJN19850016.

Sweeney, B. C., J. Rushen, D. M. Weary, and A. M. de Passillé. 2010. Duration of weaning, starter intake, and weight gain of dairy calves fed large amounts of milk. J. Dairy Sci. 93:148-152. https:/ /doi.org/10.3168/jds.2009-2427.

Tamate, H., A. D. McGilliard, N. L. Jacobson, and R. Getty. 1962. Effect of various dietaries on the anatomical development of the stomach in the calf. J. Dairy Sci. 45:408-420. https://doi.org/10 .3168/jds.S0022-0302(62)89406-5.

Terré, M., M. Devant, and A. Bach. 2007. Effect of level of milk replacer fed to Holstein calves on performance during the preweaning period and starter digestibility at weaning. Livest. Sci. 110:82-88. https://doi.org/10.1016/j.livsci.2006.10.001.

Thielemans, M.-F., E. François, C. Bodart, A. Thewis, F. Dupont, L. Lallemand, and C. Malburny. 1978. Mesure du transit gastrointestinal chez le porc à l'aide des radiolanthanides. Comparaison avec le mouton (Measurement of gastrointestinal transit in pigs using radioactive lanthanides. Comparison with sheep). Ann. Biol. Anim. Biochim. Biophys. 18(2A):237-247. https://doi.org/10 .1051/rnd:19780203.

Wang, L., D. Wu, T. Yan, and L. Wang. 2018. The impact of rumen cannulation on the microbial community of goat rumens as measured using $16 \mathrm{~S}$ rRNA high-throughput sequencing. J. Anim. Physiol. Anim. Nutr. (Berl.) 102:175-183. https://doi.org/10 $.1111 /$ jpn.12676.

Wang, R., M. Wang, X. M. Zhang, J. N. Wen, Z. Y. Ma, D. L. Long, J. P. Deng, and Z. L. Tan. 2019. Effects of rumen cannulation on dissolved gases and methanogen community in dairy cows. J. Dairy Sci. 102:2275-2282. https://doi.org/10.3168/jds.2018-15187.

Wang, Z., C. O. Elekwachi, J. Jiao, M. Wang, S. Tang, C. Zhou, Z. Tan, and R. J. Forster. 2017. Investigation and manipulation of metabolically active methanogen community composition during rumen development in black goats. Sci. Rep. 7:422. https://doi .org/10.1038/s41598-017-00500-5.

Warner, R. G., W. P. Flatt, and J. K. Loosli. 1956. Dietary factors influencing the development of the ruminant stomach. J. Agric. Food Chem. 4:788-792. https://doi.org/10.1021/jf60067a003.

Yáñez-Ruiz, D. R., L. Abecia, and C. J. Newbold. 2015. Manipulating rumen microbiome and fermentation through interventions during early life: a review. Front. Microbiol. 6:1133. https://doi.org/10 $.3389 /$ fmicb.2015.01133.

\section{ORCIDS}

Lisa-Maria Tümmler () https://orcid.org/0000-0002-4562-7777

Michael Derno ํ https://orcid.org/0000-0001-8932-2564

Petra Wolf $\odot$ https://orcid.org/0000-0003-0760-6067

Björn Kuhla @ https://orcid.org/0000-0002-2032-5502 